\title{
THE EFFECT OF TOOTH FORM ON THE INCIDENCE OF LOWER THIRD MOLAR IMPACTION (Study report)
}

\author{
M.Hendra Chandha* Mansjur Nasir** \\ Oral Surgery Department ** Orthodontic Department \\ Dentistry Faculty of Hasanuddin University
}

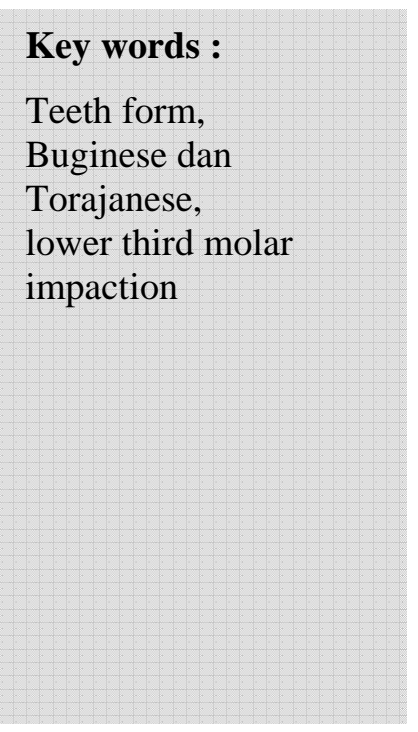

\begin{abstract}
Teeth dimension is the factor influenced the incidence of tooth impaction. The most related factor with teeth dimension is teeth form. This study was aimed to determine the effect of teeth form on the incidence of lower third impaction. It was carried out on Buginese and Torajanese in South Sulawesi Indonesia. The samples consist of 115 Buginese and 115 Torajanese, the age range from 20-25 years old with all natural mandibular teeth including second molar. After impression of both upper and lower teeth was taken, each tooth form was determined by measurement with trubite tooth indicator. The frequency distribution and coefficient corelation analysis test showed that there was no significant difference between teeth form and incidence of lower third molar impaction in Buginese and Torajanese as well as the sex. Generally, Buginese hare ovoid while Torajanese hare square teeth form.
\end{abstract}

\section{Introduction}

Tooth impaction incidence increases with time, on the other hand, the diagnostic method for detection and prevention involving family history, visual and palpasion examination in certain age with radiographic assesment was still not satisfied. If this condition was identified early on the specific case, tooth impaction extraction can be performed earlier so that further complication can be prevented. ${ }^{1,2,3,4}$

Archer (1975) showed that the frequency of upper third molar impaction was more than lower third molar. In Indonesia, however, according to Sitanggang (1975) the incidence of 
lower third molar impaction is more than upper third molar impaction. ${ }^{5,6}$

There are several factors causing tooth impaction; they are the density of surrounding tissue, primary tooth retention, premature lost of the primary tooth, less space for eruption, and narrow jaw due to the imperfect of jaw growth as well. According to the Mendel's theory, if one of the parents (mother) has small jaw, and father has big teeth, there is a possibility of the children to have small jaw and big teeth. It can result in limited space for permanent teeth and impaction will be occured. ${ }^{7}$

The most possibility influenced on tooth impaction is the dimension of the teeth. And the factor which has closed relation with teeth dimention is teeth form. Tooth form was determined in conception. It is necessary to keep in mind that permanent teeth did not change since eruption. Generally, primary teeth have proper dimention and form that locating regularly on maxilla and mandibula. However , when primary teeth were lost and there is no interdental spacing, it was assumed that the space would not enough for the successor eruption causing crowded teeth and impaction. 8

The basis of human tooth form could be understood easily by making comparation with the tooth dimention of lower level animal. Phisiological importance of important signs of teeth would be obtained after learning about the development and teeth relation on its function. Careful explanation of individual tooth dimension will give many meanings. Paleontologist found that primordial dimension of the tooth was cone. ${ }^{9}$

Teeth form is most affected by gen, sex and the function of each tooth. For example, incisive of male is square with the square distal angle, while for female, the incisive dimension is ovoid with the round distal angle. ${ }^{9}$

Generally, impaction is a condition where a tooth does not erupt to reach its normal position. Tooth impaction can be partially or throughly prohibited by its adjacent tooth, bone or surrounding soft tissue to reach its normal position. ${ }^{2,5,10,11}$ Tooth impaction can be differed with malposition, that is the tooth which erupts or unerupts in abnormal position on maxilla or mandibula, can be mesially/distally, buccally/lingually while impaction was the tooth unerupted or not penetrate oral mucosa where as erupting periode was passed. ${ }^{5,10}$

Human being has an unique teeth form with different proportion. We have different perception on good an harmonized tooth form, along with the increasing of tooth impaction incidence.

Many studies showed that teeth form has closed effect on malposition. ${ }^{8}$ Based on this, it was assumed that there is an association between teeth form and tooth impaction.

The aim of this study was to determine the effect of teeth form on the lower third molar impaction in Buginese and Torajanese.

\section{Subjects and Methods}

To obtain the information about the effect of teeth form on lower third molar impaction, epidemiological study with cross sectional approach was carried out.

The study was performed on a population that meet the sampling criteria; they were 20 25 years old, have all natural teeth including second molar, the permanent teeth had never been extracted, no sistemic disease, no caries or proximal filling, simetrical facial performance, they were ready to be a sample, and there is no history of orthodontics treatment have been carried out.

The sample were taken from sub race Deutero Malay ( Buginese ) and sub race Proto Malay ( Torajanese ), by counting $\mathrm{N}$ for each sub race. Sampling was taken by purposive non random sampling.

The material used in this study were alginate, stock tray, rubber bowl, spatle, hard gypsum and water.

To know the teeth form, the impression of upper and lower teeth was taken with stock tray and alginate so at we got negative impression and then poured with hard gypsum to get positive model for upper and lower jaw. Line was made with pencil on labiopalatal border, cervical line, and incisal edge for upper incisive. 
Teeth form was determined based on the lines. Each tooth form was determined by measurement with trubyte tooth indicator. The results were recorded, and the effect of teeth form the lower third molar impaction was analyzed.

Data was analyzed using frequency distribution and coefficient corelation analysis with SPSS programme for windows versi 10 .

\section{Results}

This study about effect of teeth form on the lower third molar impaction was carried out in 230 samples consisting of 115 Buginese and 115 Torajanese. From Buginese, the samples consisted of 43 males and 72 females, while from Torajanese, it consisted of 46 males and 69 females. After analyzing on upper incisive form of all samples, the results were follows as in tables.

According to the result on table 1 , we know that from 115 Buginese, 34 person (29,56 $\%)$ have tappered teeth form, 49 persons $(42,61$ $\%)$ have ovoid teeth form, and 32 persons $(27,83 \%)$ have square teeth form. Where as from 115 Torajanese, 26 persons (22,61 \%) have tappered teeth form, 17 persons $(14,78 \%)$ have ovoid teeth form, and 72 persons (62,61 $\%$ ) have square teeth form.

The relationship between teeth form and sex on Buginese, based on the table 2 above, can be determined that from 72 females, 19 persons (26,40\%) have tappered teeth form, 36 persons (50\%) have ovoid teeth form, and 17 persons $(23,61 \%)$ have square teeth form. Where as from 43 males, 15 persons (34,83\%) have tappered and square teeth form, 13 persons $(30,23 \%)$ have ovoid teeth form.

Table 1. Teeth form of Buginese and Torajanese

\begin{tabular}{llll} 
Feeth & Tribe & $\begin{array}{c}\text { Buginese } \\
(\mathrm{n}=115)\end{array}$ & $\begin{array}{c}\text { Torajanese } \\
(\mathrm{n}=115)\end{array}$ \\
\hline Tapper & $34(29,56 \%)$ & $26(22,61 \%)$ & \\
Ovoid & $49(42,61 \%)$ & $17(14,78 \%)$ & \\
Square & $32(27,83 \%)$ & $72(62,61 \%)$ & \\
\hline
\end{tabular}

Table 2. Relationship between teeth form and sex on Buginese

\begin{tabular}{lll}
\hline Teeth form & Female $(\mathrm{n}=72)$ & Male $(\mathrm{n}=43)$ \\
\hline Tapper & $19(26,40 \%)$ & $15(34,83 \%)$ \\
Ovoid & $36(50 \%)$ & $13(30,23 \%)$ \\
Square & $17(23,61 \%)$ & $15(34,83 \%)$ \\
\hline
\end{tabular}

Table 3 showed that from 69 females, 17 persons $(24,69 \%)$ have tapered teeth form, 11 persons $(15,94 \%)$ have ovoid teeth form, and 41 persons $(59,42 \%)$ have square teeth form. Whereas on 46 males, 9 persons $(19,56 \%)$ have tappered teeth form, 6 person $(13,04 \%)$ have ovoid teeth form, and 31 person (67,39\%) have square teeth form.

Table 3. Relationship between teeth form and sex on Torajanese

\begin{tabular}{lll}
\hline Teeth form & Female $\mathrm{n}=69$ & Male $\mathrm{n}=46$ \\
\hline Tapper & $17(24,69 \%)$ & $9(19,56 \%)$ \\
Ovoid & $11(15,94 \%)$ & $6(13,04 \%)$ \\
Square & $41(59,42 \%)$ & $31(67,39 \%)$ \\
\hline
\end{tabular}

Table 4 showed that 60 persons female on Buginese (83.33\%) have lower third molar impaction, and 62 persons female on Torajanese $(89,85 \%)$ have lower third molar impaction. Where as 37 males (86.05 \%) on Buginese and 38 males $(82.61 \%)$ on Torajanese have lower third molar impaction.

Table 4. Percentage of lower third molar impaction on buginese and torajanese with sex.

\begin{tabular}{lll}
\hline Trible & Female & Male \\
\hline Buginese & $60(83.33 \%)$ & $37(86.05 \%)$ \\
Torajanese & $62(89.85 \%)$ & $38(82.61 \%)$
\end{tabular}

Based on table 5, from 115 Buginese, 97 persons have lower third molar impaction, only 18 persons do not have lower third impaction. Where as from 115 Torajanese, 100 persons have lower third impaction and only 15 persons do not have lower third impaction. 
Table 5. Effect of teeth form on the lower third molar impaction on Buginese and Torajanese

\begin{tabular}{lllll}
\hline \multirow{2}{*}{ Teeth } & \multicolumn{3}{c}{ Impaction } & \multicolumn{3}{l}{ Not impaction } \\
\cline { 2 - 5 } Form & Buginese & Torajanese & Buginese & Torajanese \\
& $(\mathrm{n}=97)$ & $(\mathrm{n}=100)$ & $(\mathrm{n}=18)$ & $(\mathrm{n}=15)$ \\
Tapper & $29(29.90 \%)$ & $22(22 \%)$ & $5(27.78 \%)$ & $4(26.67 \%)$ \\
Ovoid & $43(44.33 \%)$ & $14(14 \%)$ & $6(33.33 \%)$ & $3(20 \%)$ \\
Square & $25(25.77 \%)$ & $64(64 \%)$ & $7(38.89 \%)$ & $8(53.33 \%)$ \\
\hline
\end{tabular}

From 97 persons who have impacted teeth, 29 persons $(29.40 \%)$ have tappered teeth form, 43 persons (44.33) have ovoid teeth form, and 25 persons (25.77) have square teeth form. While 18 persons of Buginese do not have lower third molar impaction, 5 persons (27.78 $\%)$ have tappered teeth form, 6 persons (33.33 $\%)$ have ovoid teeth form and 7 persons (38.89 $\%$ ) have square teeth form.

On Torajanese, from 100 persons who have lower third molar impaction, 22 persons (22\%) have tappered teeth form, 14 persons (14 $\%)$ have ovoid teeth form, 3 persons (20\%) have tappered teeth form, and 8 persons (53.33\%) have square teeth form.

The result coefficient corelation analysis teeth form with impaction teeth on Buginese and Torajaneses we can see in table 6 and 7. On Buginese, impaction teeth (87,7 \%) most occur on ovoid teeth form. Relationship teeth form with impaction teeth on Buginese no significant difference $(p=0,546)$. The different result was obtained on Torajanese we can see on table 7 . The different was obtained on Torajanese, impaction teeth ( 88,9 \%) most occur on square teeth form. Relationship teeth form with impaction teeth on Torajanese no significant difference $(\mathrm{p}=0,380)$.

Table 6. Relationship teeth form with impaction teeth on Buginese

\begin{tabular}{lcccccc}
\hline Teeth form & \multicolumn{2}{c}{$\begin{array}{l}\text { Impaction } \\
\text { n }\end{array}$} & \multicolumn{2}{c}{ Not Impaction } & Total & $\mathrm{p}$ \\
\hline & & & & & \\
Ovoid & 43 & 87,8 & 6 & 12,2 & 49 & 0,546 \\
Tapper & 29 & 84,8 & 5 & 15,2 & 33 & \\
Square & 25 & 78,8 & 7 & 21,2 & 33 & \\
\hline
\end{tabular}

Table 7. Relationship teeth form with impaction teeth on Torajanese

\begin{tabular}{lcccccc}
\hline Teeth form & \multicolumn{2}{c}{ Impaction } & \multicolumn{2}{c}{ Not Impaction } & Total & $\mathrm{p}$ \\
& $\mathrm{n}$ & $\%$ & $\mathrm{n}$ & $\%$ & $\mathrm{n}$ & \\
\hline Ovoid & 14 & 76,5 & 4 & 23,5 & 17 & 0,380 \\
Tapper & 22 & 88,5 & 3 & 11,5 & 26 & \\
Square & 64 & 88,9 & 8 & 11,1 & 72 & \\
\hline
\end{tabular}

\section{Discussion}

The study result on teeth form can be seen in table 1 . In table 1 , we can see that upper central incisive form of Buginese have more ovoid form, while on Torajanese, teeth form is square. Ovoid teeth form are the characteristics of the persons who have ovoid face form, where as square teeth form came from the persons with square face form. Leon William (in Fenn et al) said that the form of upper central incisive teeth has closed relationship with the facial form. ${ }^{12}$ But according to Fenn et al (1972), this statement is not been scientific one. Because, in fact, there are individuals who have ovoid face form, but they have square teeth form. There are also to have two form of incisive in one jaw. ${ }^{12}$ In this study, if we faced the fact like that, we took form the larger dimension. It is probably caused by genetic factor. The marriage between ovoid teeth form individuals with square teeth form person, can get the combined teeth form from their parents.

On Buginese, the number of individuals with tapered and square teeth form is similar in percentage. The difference between individuals with ovoid and tappered teeth form of Torajanese is also the same. This occurred because when the samples were taken, there were many individuals who are not really Buginese or Torajanese, may be one of their parents, were come from other tribes. This proved that genetics is important as a factor influencing the diversity of teeth form in each tribe. Tooth form is determined on conception, it should be kept in mind that permanent teeth would not change since eruption. ${ }^{8}$ 
In tables 2 and 3 , the relationship between sex and teeth form on Buginese and Torajanese could be seen. From those tables, it seems that there is no relationship between sex and teeth form because there is no significant difference between male and female tooth form.

Table 4 showed the relationship between tribe, incidence of lower third molar impaction and sex. This table, showed that there was no effect of tribe and sex on the lower third molar impaction.

Genetically, Torajanese has larger jaw than Buginese, it is due to the environment factor, i.e food type. Generally Torajanese food needs greater mastication force. ${ }^{13}$ But evolution process was lined with development of human culture so that human jaw size decreased. Consequently, impaction will occur. That's why the frequency of lower third molar impaction on Buginese and Torajanese is similar. Beside environment factor, this is also caused by genetic factor. Torajanese who got married with the person from other tribe who genetically have smaller jaw, will get children who have impaction teeth. It is also caused by inheritance from their parents genetically, who have large teeth and jaw or small teeth and jaw. From this study, we know that, large jaw dimension which is the characteristic of Torajanese is not theirs now, because they have evoluted by environment factor. They have change their food. This is also happened on Buginese. Based on the result of the study, we can plan a preventive programme for lower third molar impaction by consuming relative hard food which can stimulate the jaw growth.

In 1936 Hellman indicated that female have risk for developing impaction tooth twice more than male, but in this study, the result is not the same. The result of the study was confirmed with Kramer and William (1970), Dachi and Howell (1961), and Waite (1987) which showed that there was no effect of sex on tooth impaction. ${ }^{14}$

Table 5 showed the relationship between tribe, tooth form, and lower third molar impaction. Based on the table, there is no effect of tooth form and tribe on the lower third molar impaction. This is contrast to Harkati $(1993)^{8}$ who indicated that the most important factors influencing impaction are size, dimension and form of the teeth. So, if teeth size affects the lower third molar impaction, then teeth form automatically affects the incidence of lower third molar impaction. But in this study, the result is different. In fact that each individual might have square, ovoid or tapper teeth form with variety in size. There fore, there is no closed relationship between teeth form and their size.

The result of research say that ovoid teeth form on Buginese (table 6) and square teeth form on Torajanese (table 7) most cause impaction. This problem is not connected with one of the impaction cause among a lot of other causes. According from hypothesis experiment that was done can be obtained that there is not relationship between the teeth form about the incidence of lower third molar impaction. Researcher say all the form of the teeth have potention for do impaction but not be caused from the form of the teeth that special but caused from the others factor that have a role in the caused impaction. Percentation of impaction that high on the ovoid and square teeth form is caused the number of the sample that most of them have the ovoid and square teeth form. On the research, there is not relationship between the teeth form and etnich group about cause of the lower third molar impaction.

\section{Conclusion}

The conclusion of this study about the effect of teeth form on the incidence of lower third molar impaction are follows.

1. Teeth form doesn't affect the incidence of lower third molar impaction

2. Third molar impaction is not affected by tribe and sex.

3. Generally Buginese have ovoid teeth form, while Torajanese have square teeth form. 


\section{References}

1. Kwon.H.J., Impacted Teeth, dalam Textbook of Practical Oral and Maxillofacial Surgery, 3th.ed., Lea \& Febiger, Philadelphia, 1987, 130-144

2. Kidner, G., Noar,J., Evans, R.D., Management of The Impacted or Displaced Maxillary Canines, Primary Dental Care, 2000; 7(3): 99-102

3. Richardson,A.O., Heartwell,C.M., Tooth Selection, dalam Textbook of Complete Dentures, $5^{\text {th }} . e d$., Lea\&Ferbiger, Philadelphia-London, 1993, 305-321

4. Hufham,D.C., Vanarsdall, R.L., Factors That Relate to Treatment Duration for Patients with Palatally Impacted Maxillary Canines. AM J Orthod Dentofacial Orthop, 2001; 119(3):215-216

5. Archer, W.H., Oral and Maxillofacial Surgery, $5^{\text {th }} . e d .$, Vol I, W.B. Saunders Company, PhiladelphiaToronto, 1975, 250-390

6. Sitanggang,R.D., Impaksi Molar Tiga Mandibula dan Cara Perawatannya, Majalah PDGI, 1975; 13(1):1015
7. ...www.Indomedia.com/intisari/2000/April/gigi4.ht m. " Rahang Sempit, Si Bungsu Menebar Rasa Sakit “. Diakses tanggal 30 Juni 2004

8. Harkati, D., Aspek-aspek Epidemiologi Maloklusi, Cetakan Pertama, Gajah Mada University, Yogyakarta, 1993, 28-62

9. Itjiningsih, H. W., Anatomi Gigi, EGC, Jakarta, 1991, 263-302

10. Endang, J., Pengaruh Molar Tiga Bawah yang Impaksi, Kumpulan Naskah Ilmiah FKG Usakti, Jakarta, 1984, 110-115

11. Villena, M.R.M., Complications After Extraction of The Third Molar : A Series of 379 Extraction, SDMJ, 1999; 6:27-28

12. Fenn, H.R.B., Liddelow, K.P., Gimson. A.P., The Selection of Teeth, dalam Clinical Dental Prosthetics, $2^{\text {nd }}$.ed., Stapples Press, London, 1972, 224-234

13. Patricia, I., Pengaruh Bentuk dan Ukiran Lengkung Gigi Terhadap Terjadinya Impaksi Gigi Molar Tiga Rahang Bawah. Skripsi FKG-UH, Makassar : 2004

14. Waite DE. Textbook of Practical Oral and Maxillofacial Surgery. $3^{\text {rd }}$ ed. Philadelphia : Lea \& Febiger, 1987 